\title{
$3+$ \\ Att köpa eller inte köpa? \\ Hushållning och konsumtion
}

Slutet av I800-talet och början av I900-talet brukar beskrivas som en period av ekonomisk uppgång i Sverige, men också som en tid av stora konjunkturväxlingar och förändrade sociala förhållanden. Den ekonomiska tematiken är framträdande i periodens litteratur och det finns många berättelser om skuldsedlar och konkurser, fordringsägare och fattigadel. Ruinerade familjer är även rikligt förekommande i sekelskiftets svenska flickböcker, men där innebär kriserna ofta en möjlighet till större frihet och ökat självbestämmande för de unga kvinnorna. I många flickböcker blir den ekonomiska problematiken också en del av en kritik mot samtidens könsstrukturer genom att det är männen som försätter familjerna i skuld, medan kvinnornas driftighet räddar dem.

Under andra hälften av I 800-talet förändrades kvinnors ekonomiska ställning genom flera reformer. Avskaffandet av skråtvånget I 846 medförde att nya arbetsområden öppnades för kvinnan, medan yrken som folkskollärare, kontorsarbetare och läkare successivt blev tillgängliga under seklets senare hälft. Det innebar att fler kvinnor kunde hitta socialt accepterade sätt att försörja sig utanför hemmet och familjen. ${ }^{285}$ De fick också ökade möjligheter att bestämma över sin ekonomi genom förändrad lagstiftning. Några viktiga lagändringar var införandet av lika arvsrätt för kvinnor och män I 845 , de olika myndighetsreformerna mellan I 858 och I92 I, samt lagen om gift kvinnas äganderätt I 874. Reformerna berörde till en början främst den ogifta kvinnans rättigheter, medan gifta kvinnor juridiskt längre betraktades som del av en familjeenhet med maken som hushållets ekonomiska förvaltare och representant i offentlig- 
heten. ${ }^{286}$ Från I 862 erhöll myndiga kvinnor (det vill säga ogifta och änkor) kommunal inkomstgraderad rösträtt. En förmåga att hushålla med pengar och resurser var således inte bara väsentligt för privatekonomin utan kunde ge kvinnor möjlighet att påverka lokalsamhällets utveckling.

De olika reformerna öppnade nya vägar för sekelskiftets unga kvinnor, men innebar också annorlunda krav. Langlet konstaterade i På egen hand från I 889: "Qvinnan måste nu stiga fram och deltaga i kampen för tillvaron, i kampen om bröd, måste de bära de tunga bördorna av lifvets allvar och får icke nu jollra bort ens sin ungdomstid."287 Även flickor förväntades ta ett större ansvar och aktivt förbereda sig för sitt kommande familje- eller yrkesliv, genom utbildning i eller utanför hemmet. Den ekonomiska tematiken i de svenska flickböckerna formuleras ofta som ett spänningsfält mellan hushållning och slöseri, eller - för att använda Orsi Husz terminologi - rationell och hedonistisk konsumtion. ${ }^{288}$ Dikotomin sammankopplas parallellt med andra motsättningar, mellan landsbygd och storstad, tradition och modernitet, samt svenskt och utländskt. ${ }^{289}$ Därigenom skapas en kontrast mellan olika sociala och ekonomiska modeller, som används för att diskutera kvinnans roll i samhällslivet och vilka värden som ska vara rådande.

I det följande kommer jag att undersöka vilken funktion ekonomiska aspekter har i de svenska flickböckernas framställning av mognad och vuxenblivande, samt hur kön produceras i relation till arbete och ekonomi. Som många forskare har påpekat har konsumtion ofta sammankopplats med kvinnor eller feminisering. I synnerhet den hedonistiska konsumtionen, som är inriktad på nöje och begärstillfredsställelse, har givits kvinnliga förtecken. Kvinnorna har framställts som mer hedonistiska än männen och deras konsumtion har beskrivits på ett mer nedlåtande sätt. ${ }^{290} \mathrm{Om}$ den hedonistiska konsumtionen sammankopplas med lyx och drömvärldar, är rationell konsumtion fast förankrad i en måttfull vardag och strävar efter att tillgodose de mest nödvändiga behoven. Den kännetecknas av sparsamhet, planering och förnuftiga inköp. ${ }^{291}$ Sinnebilden för den rationella konsumenten i Sverige utgjordes runt sekelskiftet 1900 av den goda husmodern och sparsamhet framställdes av förespråkare för kvinnlig rösträtt som en kvinnlig egenskap. ${ }^{292}$ I de svenska flickböckerna förkroppsligas de två livshållningarna av olika 
karaktärer som lite förenklat kan kallas den husmoderliga och den hedonistiska flickan, vilka kommer att stå i fokus i min diskussion. För en senare barngeneration har typerna kommit att representeras av Birgitta Lilliehööks tecknade serie om flickorna Spara och Slösa, som publicerades i Lyckoslanten mellan 1926 och I963, men karaktärerna har som synes betydligt äldre rötter.

\section{Ekonomi och arbete ur kvinnoperspektiv}

Kvinnors arbete under I 800-talet utgjordes till stora delar av oavlönade sysslor, men innebar ändå ett väsentligt bidrag till familjens ekonomi. Majoriteten av befolkningen bodde på landsbygden och för att vardagen skulle fungera krävdes att båda makarna arbetade. I egenskap av husmoder förväntades kvinnan såväl vara en god arbetsledare som själv delta i sysslorna, också i de övre klasserna. Hennes ansvarsområden rörde bland annat textiltillverkning, livsmedelsberedning och trädgårdsoch smådjursskötsel. ${ }^{293}$ Som Leif Runefelt har konstaterat i sin studie om svensk konsumtionsdebatt från I700-tal till tidigt I800-tal var den sparsamma hustrun ett ideal med stark kraft under perioden. ${ }^{294}$ Genom utbredningen av en mer formaliserad hushållsundervisning under senare delen av seklet befästes detta ideal, samtidigt som en professionalisering av husmoderns arbete inleddes. ${ }^{295}$ Skapandet av utbildningar i huslig ekonomi och hemkunskap innebar parallellt fler tillfällen till lönearbete för kvinnor i nya yrken som hushållslärare och, en bit in på 1900-talet, hemvårdskonsulent. ${ }^{296}$

Den höga värderingen av husmoderskapet byggde, som tidigare påpekats, på en könsarbetsdelning där hemmets förvaltning och drift i hög grad var kvinnans ansvarsområde. I Wides Kamraterna på Forsbro poängteras att hustrur genom att själva ta del i hushållssysslorna "förvärfva och behålla mannens aktning, såsom det måste ske, när han ser att vi verkligt arbeta för att fylla vår plats. Hvarför skall också han ensam arbeta och vi lägga händerna i kors samt bara fordra mer och mer såväl af honom som af tjänare?"297 Gifta par förväntas genom sina olika arbetsuppgifter bidra till hemmet och bådas insatser framställs som grundläggande för ett harmoniskt samliv. Citatet antyder även att ett väl 
utfört hushållsarbete kunde stärka kvinnans position inom äktenskapet då hon vinner mannens respekt. Liknande tankegångar har framförts av Peder Aléx som menar att synliggörandet och uppvärderingen av kvinnans sysslor under I800-talet bekräftade traditionella föreställningar om kön och arbete, men också kunde fungera emancipatoriskt. Den professionalisering av husmoderns sysslor som hushållsutbildningen innebar kan ha påverkat maktbalansen $i$ hemmen och låtit kvinnor inta en mer jämbördig ställning med männen. ${ }^{298}$

Under I700-talet och det tidiga I 800-talet framställdes husmodern som handlingskraftig och kunnig inom hushållsområdet, men hon tilläts inte visa självständighet. ${ }^{299}$ Kunskap om hushållning i flickböcker utgör tvärtom ofta en väg till större oberoende och ekonomisk trygghet. Anna i Ellen Idströms Tvillingsystrarna. Berättelse för unga flickor (I 893) tillbringar visserligen ingen tid med köksarbete, men undervisas i trädgårdsskötsel och får huvudsakligen sina slantar genom att sälja de bär och grönsaker som hon odlat. Hennes förmyndare önskar på så vis lära henne att bli ekonomiskt ansvarstagande:"Jag har velat, att du i tid skall lära dig att handhafva pengar och veta hvad de äro värda." ${ }^{300}$ Flickan kontrasteras mot tvillingsystern som fått rikliga fickpengar och utvecklat slösaktiga vanor. Då Anna på olika sätt måste förtjäna sina pengar lär hon sig hushållning och att spendera dem på väsentligheter. Även $\mathrm{i}$ Stadsflickor på landet lär sig eleverna att dryga ut hushållskassan genom att väva bomullslärft för såväl eget bruk som försäljning. Trots att hushållsskolan i Andersons roman främst syftar till att lära flickorna att bättre sköta de egna hemmen, framhålls att kunskaperna kan vara viktiga för att trygga deras framtid. Tunga sysslor som grovtvätt förväntas tvätterskor ta hand om, men ändå sägs det vara positivt för eleverna från de högre klasserna att få insyn i hur det arbetet går till. Det poängteras av en av tvätterskorna: "'Lärdomen är inte tung att bära', menade hon, 'och ingen kan veta, hvad man kan komma att behöfva. Min far var klockare', tillade hon, 'och ändå är jag fattig nu på gamla dagar."301 De unga kvinnorna bör förberedas för en ekonomiskt osäker framtid. Hushållsundervisningen ger dem den praktiska kunskapen för att utföra många typer av arbete och gör dem bättre rustade att möta eventuella finansiella svårigheter. 
Att medel- och överklassflickor kunde bli tvungna att försörja sig själva som vuxna framställs som en realitet i i80o-talets och det tidiga I900-talets flickbok. De unga kvinnornas yrkesarbete motiveras ofta av just tvingande ekonomiska omständigheter. Den offentliga fattigvårdens insatser var begränsade och möjligheten till understöd ökade om de hjälpsökande visade en vilja till arbete. ${ }^{302}$ Såväl skuldsättning som olika former av ekonomisk uppgång och fall är vanligt förekommande i periodens litteratur för både barn och vuxna. ${ }^{303}$ Det finns i det analyserade materialet en rik förekomst av familjer som nyligen har förlorat sin förmögenhet eller som gör det under berättelsens gång. I Emily Nonnens Familjen på Örnaholm eller Lifvets skiften. Berättelse för ungdom (I 863) mister en överklassfamilj sin ställning då fadern visar sig vara trädgårdsmästarens och inte en överstes son, Malvina Bråkenhielms Marja och hennes syskon. Berättelse för unga flickor (I9I2) följer en änka med familj som efter makens död försörjer sig genom inackorderingar, medan Svedenborgs Blomkulla-serie skildrar hur adelssläkten Lagerstam förlorar godset Blomkulla på grund av en bankkrasch. De förändrade förhållandena kan innehålla moraliska implikationer, som i Nonnens roman där familjens ekonomiska förfall framstår som en följd av ungdomarnas okänsliga agerande mot en blind tiggare, vilket förutspås av hans klagande ord: "ve öfver det hus, där man hånar den fattige, det skall snart ramla, och de, som skryta öfver sin härlighet månde nog finna, att den ej tillhör dem mera, och då skola de gråtande vända sig därifrån". ${ }^{304}$ Andra texter illustrerar på ett mindre moraliserande sätt tidens ekonomiska oro och instabilitet. Familjen Lagerstam blir i Svedenborgs Bröllopet på Blomkulla. En bok för flickor (1923) ett offer för aktiemarknadens fluktuationer, liksom många familjer i I 920-talets finansiella omvälvningar. Detta sker inte som en konsekvens av bristande moral, utan snarare på grund av alltför stor lojalitet mot en bank som de under många år varit kunder hos. De är trogna ett äldre ekonomiskt tänkande där tradition och sociala relationer värderas högre än marknadsekonomins flyktiga kontakter och vinstintresse.

Medelklassen utgör vanligtvis en outtalad norm i tidens flickböcker och liksom i periodens barn- och ungdomslitteratur i stort förmedlas denna klass livsmål och värderingar. ${ }^{305}$ Gunnar Örnulfs trilogi om Anna 
Jernhielm (1919-22) är ovanligt explicit i behandlingen av karaktärernas monetära situation. Ett flertal av adelsfamiljerna i berättelsen har gått i konkurs eller närmar sig ruinens brant. Männen har förslösat sina arv på nöjen och oförnuftiga investeringar. Alternativen de ställs inför är att gifta sig rikt eller att ställa om sin verksamhet till en ny tids krav. De som nått framgång utgörs signifikativt nog av en bankirfamilj och Annas blivande make Rudolf Sporre. Mannen drivkraft och arbetsvilja antyds av det symboliska efternamnet. Rudolf vill inte"sälja sig" genom att göra ett gott parti utan i enlighet med medelklassens normsystem föredrar han att "själv skapa sig en framtid" som grosshandlare. ${ }^{306}$

I inledningen av den andra boken, Anna Jernbielms friare. Flickroman (I920), har även huvudpersonens familj drabbats av ekonomiska svårigheter då familjens lantbruk drivits på ett ineffektivt, gammaldags vis. Egendomen har gått med "förfärande förluster" och fadern har tagit "allt högre och högre inteckningar". ${ }^{307}$ De står inför hotet att banken på grund av tidens ekonomiska läge kan komma att ta ifrån dem lantegendomen om skulderna blir alltför stora. Fadern påstås också ha skämt bort sina torpare genom att ge dem förmåner som de borde betala för med pengar eller arbete. Enligt Rudolf måste de"reda sig med sitt arbete, liksom alla människor, i stället för att leva på nådegåvor". ${ }^{308}$ Romanen formulerar därigenom en medelklassens pliktetik, som förespråkar idoghet, förnuft och arbetsmoral. En liknande syn på de lägre klasserna uttrycks i Wides Kamraterna på Forsbro i beskrivningen av hur lågkonjunkturen påverkat lantortsbefolkningen:

\footnotetext{
Där går den stackars landtbefolkningen, arbetar och knogar året om men kommer aldrig upp till något välstånd. Det beror nu dels på ogynnsamma år, dels på ständigt nedsatta priser på alla landtmannaprodukter, men dels äfven på bristande företagsamhet. Särskildt är det illa ställdt med kvinnorna. De kunde mången gång ha god tid att arbeta på förtjänst men veta rakt inte hvad som kan löna sig och kunna förstås ej ligga i förskott för arbetsmaterial, när det är ovisst att få själfva arbetet såldt. ${ }^{309}$
}

Beskrivningen kännetecknas av såväl empati som ett viss mått av nedlåtenhet. Lantortsbefolkningens svaga ekonomi förklaras med dåliga 
tider, men också med bristande kunskap och initiativkraft. Till skillnad från de övre klasserna förmår de inte ta sig ur sin belägenhet på egen hand.

Om flickböckerna i begränsad utsträckning för en kritisk diskussion runt klasstrukturer och ojämlika sociala förhållanden, sätter de i betydligt högre grad fokus på hur den finansiella osäkerheten påverkar kvinnornas liv. I citatet från Wides roman ovan poängteras att landsbygdens kvinnor har det särskilt svårt och i Örnulfs trilogi nämns i förbigående hur flickor drabbas av familjernas ekonomiska problem:

Hedvig kände flickor, vilkas fäder dött och lämnat efter sig familjen i det mest fullständiga armod, flickor som efter en lycklig barndom kastats ut i livet för att på egen hand kämpa en hård och förbittrad kamp för det dagliga brödet. Hon skulle ha kunnat berätta om det liv av bittra försakelser och missräkningar som så många ensamma, självförsörjande flickor få föra i storstadsvimlet $[\ldots]^{310}$

Att faderns död utpekas som en vändpunkt för flickorna i Örnulfs berättelse är karakteristiskt. När familjer går i konkurs i I 800-talets och det tidiga I900-talets svenska flickböcker är det ofta faderns bristande ekonomiska handlag som orsakar problemen. Förvaltare Borgs slösaktiga leverne i Meyersons Flickor emellan leder till att hus och bohag måste säljas på auktion vid hans bortgång, medan fadern i Marja och hennes syskon lämnar efter sig"till ytterlighet tilltrasslade affärer med skulder som tillät familjen endast behålla en del av boet" ${ }^{311}$ För familjerna blir konsekvensen vanligen, som i Meyersons och Bråkenhielms texter, att de tvingas lämna sitt hem för blygsammare bostäder och i många fall även överge det tidigare levernet och umgänget. Dessa berättelser synliggör kvinnors särskilt sårbara situation i I 800-talets och det tidiga I900-talets patriarkala samhälle, då de ställs ensamma med skulder och försörjningsansvar, men med begränsad möjlighet till utbildning och yrkesarbete. ${ }^{312}$

De många män som lever över sina tillgångar kan också ses som en kritik av den utbredda kreditbaserade handeln, som enligt Aléx debatterades under stora delar av I800-talet och I900-talets förra hälft. Möj- 
ligheten att köpa på kredit påstods locka till överdriven konsumtion och likgiltighet inför den personliga ekonomin, vilket ledde till sedeslöshet och att lyckliga hem förföll i misär. Lösningen sades ligga i kontanthandel och hushållning. Genom att bara köpa det man kunde betala för utvecklades man till en ansvarskännande, god medborgare som förmådde hantera såväl den egna som samhällets ekonomi. Husmodern gavs en nyckelroll i kampen mot krediten, men hennes situation kunde försvåras av att hon saknade makt över familjens ekonomi. ${ }^{313}$ I Meyersons flickbok förmår inte heller modern stävja makens yviga spenderande. Med konkurserna sker dock ett maktskifte mellan könen. Om männen förslösat förmögenheten, räddas hemmen i stället av kvinnlig driftighet. Det kan handla om införandet av en strikt hushållning eller skapandet av nya inkomsttillfällen, som i Wides flickbok där torparkvinnorna börjar med hemslöjd. Nybloms Väninnorna skildrar hur två föräldralösa flickor försörjer sig genom trädgårdsodling och torghandel, medan Hanna i Svedenborgs Bröllopet på Blomkulla överväger att låta sig och tvillingsystern Lena utbildas i hushållskunskap respektive sömnad för att förtjäna och spara pengar. Själv önskar hon

gå igenom en riktig husmoderskurs. För om jag också redan kan en del, så måste man $\mathrm{i}$ alla fall ha betyg om man ska förtjäna sitt bröd själv. Lena ska gå igenom Birgittaskolan och lära sig sy vackra kläder av ingenting åt oss allesammans för fem kronor om dagen. ${ }^{314}$

Det är dock främst en yngre generation kvinnor som förmår axla en ny tids krav. I Nybloms, Meyersons och Wides romaner är det döttrarna snarare än mödrarna som i krisens stund visar handlingskraft. När modern i Kamraterna på Forsbro håller på att gå under av de ekonomiska svårigheterna vaknar dottern Erikas energi och hon ordnar medel så att de mest brådskande skulderna kan betalas.

Snarare än att sörja den förlorade förmögenheten tar sig många flickboksprotagonister an den nya, mer aktiva tillvaron med tillförsikt. De finner ett nöje i att arbeta, bidra till familjens ekonomi eller försörja sig själva. ${ }^{315}$ Den självkänsla och glädje som skapas av att ha en uppgift är framträdande i periodens flickböcker. Alcott var en av dem som ofta 
berörde frågan om kvinnans arbete och i exempelvis An Old-Fashioned Girl (I869-I870, sv. I870) behandlas såväl svårigheten för en kvinna att hitta ett tillräckligt inkomstbringande yrke som den glädje en kvinnlig arbetsgemenskap kan ge. ${ }^{316}$ Som Birgitta Theander poängterat utgör arbetsskildringar likaledes en framträdande aspekt av I900-talets svenska flickböcker. ${ }^{317}$ Yrkesarbetandet möjliggör kvinnans utveckling till en självständig person, som inte längre definieras av äktenskapsstatus eller familjenamn utan med utgångspunkt i sina färdigheter. Texterna betonar även det fysiska arbetets hälsobringande verkan. I Kamraterna på Forsbro framhålls att arbete och sport" härdar och utvecklar kroppen och håller sinnet friskt". ${ }^{18}$ Den positiva framställningen av fysisk aktivitet går därmed i dialog med en idealbildning där medel- och överklassflickorna huvudsakligen förväntas, som i Ebba af Silléns Majs pensionsår. Berättelse för unga flickor (I9I2),"sprida glädje och trevnad i hemmet". ${ }^{319}$ I stället betonas att unga kvinnor har behov av sysselsättning och social samvaro för sin egen skull. Arbetet ger de unga kvinnorna ett eget värde och livsmål, eller som det formuleras i Meyersons Flickor emellan redan innan flickorna tvingas ta över försörjningsbördan: "[V]år vilja är bara att arbeta. Ser du, lilla pappa, det ligger i tidsandan, detta behof efter arbete." ${ }^{\prime 20}$ Längtan efter sysselsättning utgör den moderna tidens kännetecken.

\section{Den husmoderliga flickan}

Den sparsamma, flitiga husmodern är ett gammalt ideal som bland annat formuleras genom Bibeln i Ordspråksbokens beskrivning av en god hustru. Där framställs hon som aktiv från morgon till kväll med hemmets sysslor och hon odlar såväl familjens moraliska som dess materiella välstånd. En sådan kvinna är"mycket ädlare, än aldrakosteligaste pärlor" och "bergning skall honom icke fattas" om mannen sätter sin lit till henne. ${ }^{321}$ Dygdens värde beskrivs med ett ekonomiskt bildspråk, men den sägs också resultera i mer bokstavliga vinster. Det är genom sitt arbete snarare än utseende eller sällskapstalanger som hon bidrar till hemmets välstånd. Runefelt framhåller att en motbild till den goda husmodern i I700- och I 800-talens svenska konsumtionsdebatt utgjordes av den då- 
liga hustrun som slösade med både pengar och tid. Hon beskrevs som en hemmets förstörare och förkroppsligades av den fåfänga och lata kvinnliga konsumenten. I stället för att själv tillgodose familjens behov genom hushållssysslor slösade hon resurser på att köpa varor och tjänster. ${ }^{322}$

Den unga kvinnans förhållningssätt till hushållning och konsumtion blir på ett liknande sätt centralt i flickböckernas konstruktioner av kvinnlighet och vuxenblivande. I Bolanders" Törnrosen" (I840) låter en överste sina två döttrar själva inreda var sitt rum och svara för sina inköp: "Öfversten ville härigenom dels vänja sina döttrar vid hushållsaktighet och omtanka, dels pröfva och ge dem tillfälle till utveckling av deras smak och ordning." ${ }^{23}$ Beda köper enkla, smakfulla möbler och inreder sitt rum med tanke på allas trivsel, medan Josefina köper nipper och överdådiga gardiner men glömmer väsentligheter som en kommod. Rummen och inköpen speglar väl deras personligheter. Josefina är oförnuftig, slarvig och gör av med alla sina pengar i nyckfulla infall. Systern har däremot lärt sig hushållningens konst och får slantarna att räcka för såväl sina som andras behov.

Husmoderns uppgifter omfattade huvudsakligen två områden: dels att ansvara för arbetet $\mathrm{i}$ hemmet, dels att fatta beslut om hushållets inköp. ${ }^{324}$ Hushållning innebär alltså inte nödvändigtvis en negativ inställning till konsumtion. Aléx konstaterar:"Hushållningsbegreppet har mer kopplats till ett betonande av bruksvärdet. I konsumtionen skulle familjerna snarare bruka än förbruka de resurser som står till familjernas, samhällets och naturens förfogande." 325 Det handlar om att använda tillgångarna på bästa sätt och att anpassa förbrukning efter faktiska behov. En annan novell av Bolander,"Arbetsamhetens fördelar" (I 840), tydliggör sambandet mellan hushållning och behov: "Genom sin mors råd och exempel hade hon vant sig vid den största hushållsaktighet och ordentlighet, och hon hade djupt i sig inpreglad den grundsatsen: att aldrig utsträcka sina behof utöfver tillgångarna." ${ }^{326}$ Måttfullhet och att anpassa sina inköp efter de ekonomiska omständigheterna utgör en eftersträvansvärd dygd.

Vikten av att hushålla med resurser understryks också av Andersons Stadsflickor på landet. Trots att romanen på många sätt idealiserar ett självhushållningsideal poängteras att det ibland kan vara mer rationellt 
att köpa varor. När flickorna i hushållsskolan ska ställa till en bjudning för traktens fattiga barn får de användning för både sina husliga färdigheter och kunskaper i ekonomi. Utgiften för varje inköp till festen diskuteras ingående:

Först och främst skulle de nu komma öfverens om, hvad som borde köpas upp till kalaset. De inbjudna gästerna voro femton till antalet. [... ] Till att börja med skulle de naturligtvis ha kaffe.

"Hvad kostar det? Och hur mycket går det åt?" undrade alla på en gång.

Maja föreslog, att man skulle köpa tre kilo malet kaffe, och erbjöd sig att föra räkenskaperna.

"Tre kilo!" utropade Anna."Nej, jag tackar, det skulle gå till fem sex kronor. Betänk att vi inte ha mer än åtta att hushålla med. Skrif:

Ett färdedels kilo kaffe ....50 öre

Grädde, en half liter ....... 37 »

Socker, ett fjärdedels kilo .. I6 $»^{327}$

Över de följande sidorna listas inkomster och prisuppgifter, och läsaren ges handfast undervisning i såväl vanliga matvarors kostnad som pengars värde.

Flickornas diskussion av inköp synliggör att hushållning förutsatte kunskap om prislägen, men också förnuft och eftertänksamhet. För att kunna vara sparsam krävdes egenskaper som viljestyrka, förmåga att planera och att inte ge efter för spontana impulser. Därigenom fungerade sparsamheten på samma gång som en moralisk värdemätare. ${ }^{328}$ Som flera forskare har framhållit finns en tradition inom flicklitteraturen där protagonisterna utbildas i och genom konsumtion. Wollstonecrafts Original Stories from Real Life och Edgeworths"The Purple Jar" skildrar till exempel hur flickor vägleds till att bli eftertänksamma konsumenter och moraliska medborgare. Megan A. Norcia menar att Wollstonecraft i sin berättelse

elevates the profile of the woman consumer, presenting her ostensibly trifling purchases as part of a larger economic and social system, showing 
that these small, personal choices are actually political and social acts which allow her to participate in the work of a commercial nation, to exercise charity, and to support her fellow Englishmen, women, and children. $^{329}$

Den kvinnliga konsumtionen tillmäts en betydelse för såväl lokalsamhället som nationen, vilket gör uppfostran av flickor till ansvarstagande konsumenter till en angelägen uppgift. Även i den finländska flickboken från sekelskiftet I90o framhävs inhemska varor och ting med förhärligande och nationalistiska tonfall. ${ }^{330}$ Ett svenskt exempel finns i Ehrenborgs Prostinnans flickskola, där prostinnan sparar pengar genom att odla cikoria - "detta inhemska kaffe" - i stället för att köpa den importerade varan. ${ }^{331}$

En ansvarsfull hushållning och måttfull konsumtion blir i dessa texter ett tecken på mognad, där en internalisering av sparsamhet och flit utgör kännetecknet för kvinnlig vuxenhet. Ofta handlar det om att avstå från egna inköp till förmån för bättre behövande, som i Strussenfelts Flickskolan på landet där de unga kvinnorna skänker sina pengar till en skuldsatt änka i stället för att köpa saker till sig själva. På samma sätt är flickornas utgifter till nytta för andra, sämre lottade personer när de ställer till en fest i Andersons flickbok. I sina inköp eftersträvar de lokalsamhällets bästa snarare än egen behovstillfredsställelse, även om glädjen att giva beskrivs som ett större nöje än att få i dessa romaner. Liknande välgörenhetsinsatser är vanligt förekommande inom flickboken. Under genrens historia har otaliga unga kvinnor organiserat sig för att sticka strumpor åt behövande, besöka ensamma äldre eller samla in pengar till behjärtansvärda ändamål. ${ }^{332}$ Dessa flickklubbar utgör ytterligare en påminnelse om tidens utbredda fattigdom och en bräcklig ekonomi. Det rättspatos och den sociala ansvarskänsla som flera flickor uppvisar har också blivit ett kännetecken för genrens godhjärtade yrhättor, såsom Wiggins Rebecca, Eleanor H. Porters Pollyanna i flickboksklassikern med samma namn från I9I3 och Ester Blenda Nordströms Ann-Mari i En rackarunge (I9I9) med efterföljande böcker. ${ }^{333}$ Utövandet av välgörenhet ingår emellertid även i medelklassens konstruktion av sig själv som moraliskt ansvarstagande och, i vissa fall, överlägsen. Att ett stråk av 
självförhärligande kunde ingå i det till synes osjälviska givandet exponeras i Elisabeth Kuylenstierna-Wensters De nio kamraterna. En skolflicksbistoria (1920). Skolflickorna har samlat in pengar för att ge sin fattiga lärarinna ett presentkort att köpa kläder för, men blir besvikna då hon till en början inte visar någon tacksamhet: "Harmen steg som en mörk flodvåg i de unga sinnena [... ."334 Avsaknaden av glädjeyttringar framhäver att välgörenheten kunde upplevas som nedlåtande eller överflödig. Genom att inte visa sig tacksam bekräftar lärarinnan inte skolflickorna som goda medborgare och accepterar inte heller positionen som underdånigt välgörenhetsobjekt som ligger implicit i relationen mellan givare och mottagare. Denna typ av kritiska perspektiv är dock ovanliga i undersökningsperiodens svenska flickböcker. Välgörenheten mot sämre lottade blir oftare en del av skapandet av över- och medelklassflickorna som empatiska, ansvarskännande subjekt.

Hushållningen handlar både om att göra förnuftiga val som konsument och om att vårda sina ägodelar. Alcotts An Old-Fashioned Girl visar hur unga kvinnor kan spara pengar genom att själva ändra sina kläder och samma lärdom poängteras i ett fiktivt parti av Langlets rådgivningsbok På egen hand om ett sybords historia:"Om man kan sjelf sy sina hvardagskläder och ändra hattar och kappor, så sparar man mera än man med något arbete skulle kunna förtjena [... ].”335 Genom att laga och sy om gamla kläder, samt själva tillverka enklare plagg, förmår flickorna i Langlets berättelse begränsa sina inköp till att enbart innefatta balklänningar och räddar därigenom faderns ekonomi. I Stadsflickor på landet sparar eleverna pengar på ett liknande sätt när de lär sig att utföra arbeten som strykning och enklare sömnad. En annan aspekt av samma tematik gestaltas av den slarviga yrhättan vars omognad bland annat signaleras genom hennes trasiga och smutsiga kläder. I Emmy von Rhodens Der Trotzkopf kretsar flera scener runt protagonisten Ilses slarviga klädsel och ovilja att ta hand om plaggen på ett passande sätt. När hon tillrättavisas framhålls hur olämpligt beteendet är för en flicka $i$ hennes ålder:

Ich kann nicht gleichgültig dabei sein, wenn du in einem so unordentlichen Kostüme dich blicken läßt. Du bist kein Kind mehr mit deinen 
fünfzehn Jahren; bedenke, daß du seit Ostern konfirmiert bist, eine angehende junge Dame aber muß den Anstand wahren. ${ }^{336}$

Ilses vuxenblivande representeras genom att hon lär sig att vårda sitt utseende och sina ägodelar, vilket samtidigt blir en inskolning i en mer konventionell kvinnlighet. Pojkflickan Tordis i Kuylenstierna-Wensters Ungdomen på Hällesund tillhör samma karaktärstyp. Hennes ökade mognad markeras visserligen inte av att hon börjar sköta om sitt yttre, men väl av att hon börjar spara pengar för att kunna bygga ett eget hem. Genom att hushålla med resurser och spara sina slantar till rätt saker visar flickorna självkontroll, ansvarstagande och - i flera berättelser solidaritet med lokalsamhället och nationen.

\section{Den hedonistiska flickan}

Många av de diskuterade flickböckerna kontrasterar ansvarstagande, husliga kvinnor mot högdragna, arbetsskygga stadsflickor, som varken förstår arbetets eller tingens värde. Hulda i Stadsflickor på landet ogillar först arbetet och är rädd för att förstöra sina händer, men året i ett lanthushåll blir ett uppvaknande. Hon konstaterar i slutet av berättelsen: "Det var på Granliden [hushållsskolan] jag lärde mig inse värdet af ett ordnadt arbetslif [...] och det var också där mina ögon började öppnas för lifvets allvar." ${ }^{337}$ Från att ha varit en fåfäng och ytlig flicka förvandlas hon till en aktiv, osjälvisk kvinna. Om det är lantvistelsen som förbereder stadsbon Hulda för vuxenlivet, finns en annan flickbokstradition där resan går åt motsatt håll. I exempelvis Clementine Helms Backfischchen's Leiden und Freuden (I 863, sv. I 885) är det stadsvistelsen som ger flickan polityr och introducerar henne i vuxenvärlden, även om vuxenhet definieras på annorlunda vis än i böckerna om hushållsskolor.

Lantflickan Anna i Örnulfs böcker utgör en svensk variant av tematiken. Hon presenteras inledningsvis som en klassisk pojkflicka med rufsigt hår, ovårdad klädsel och huvudet fullt av okynne. Liksom många tidigare flickbokshjältinnor beskrivs Anna som godhjärtad, men i behov av korrigering. Till skillnad från Hulda och andra koketta karaktärer är hon inte fåfäng. Däremot beskrivs hon som okunnig och omedveten. 
Anna sägs i en senare bok vara ointresserad av"tidens stora rörelser" och framför allt tänka"på att roa sig, på sina nöjen, vackra kläder och muntra upptåg. Alltsammans mycket oskyldigt, men tanklöst och ytligt". ${ }^{338}$ Under vistelsen i storstaden blir hon i likhet med Rhodens Ilse medvetandegjord om vikten av att bry sig om sitt utseende och om hur opassande hennes okontrollerade beteende är för en snart fullvuxen kvinna. Förändringen sker successivt i Anna Jernbielm. Flickroman (1919) och följande böcker, men en nyckelscen i den första romanen är kapitlet"På Nordiska kompaniet" där Anna får en ny garderob.

Örnulfs flickbok är publicerad relativt snart efter att Nordiska Kompaniet för första gången slog upp portarna I9I5. Städernas varuhus betraktades i samtiden som en symbol för modernitet och modern konsumtion. De var öppna för alla, hade ett fullständigt sortiment och kunderna kunde där i lugn och ro strosa runt från våning till våning och titta på varorna utan köptvång. ${ }^{339}$ Rita Felski menar att varuhuset utgjorde" a paradigm of a new kind of urban public space linked not to an ideal of political community and rational debate but to the experience of sensuality and the commercialization of desire.". 340 Till skillnad från den politiska offentligheten var det en miljö orienterad mot kvinnor, ett damernas paradis, för att citera den svenska titeln på Émile Zolas $A u$ bonheur des dames (I883, sv. I883), som också omnämns i Anna Jernbielm. ${ }^{341}$ Varuhuset var en offentlig miljö utformad för kvinnor och där kunde de träffa väninnor utanför hemmet. Det var också en plats de kunde besöka utan sina män. ${ }^{342}$

Orsi Husz har beskrivit hur Nordiska Kompaniet liknades vid en drömvärld eller ett sagopalats när det öppnades. Det är också precis så som varuhuset beskrivs i Anna Jernbielm. När Anna förs in igenom dess snurrande dörrar stannar hon mållös inför"den undervärld" som möter henne. ${ }^{343}$ Läsaren förs tillsammans med flickan genom de olika avdelningarna och beundrar överflödet av varor, lyxiga material, den lockande skyltningen och rulltrappan, som var Sveriges första. ${ }^{344}$ Varuhuset associeras med modernitet, lyx och hedonism och den unga kvinnan blir närmast berusad av upplevelsen: 
Anna kände sig till mods som en lycklig furstinna, där hon stod framför speglarna i det eleganta lilla provrummet och provade den ena dräkten efter den andra, medan hon bara behövde röra ett finger för att ögonblickligen få varje önskan tillfredsställd. ${ }^{345}$

Här finns ingen tanke på det arbete eller den kostnad som ligger bakom varorna. Inga ekonomiska hänsyn tas heller vid shoppingen utan först när flickan tröttnar på att prova kläder upphör den. Till skillnad från i berättelser om husmoderliga flickor är det inte nödvändigheten som dikterar inköpen utan modet. De kläder Anna har på sig sägs visserligen vara acceptabla på landet, men i Stockholm är de omoderna så hon måste köpa nytt.

Varuhuset innebar på olika sätt en ökad frihet och självständighet för kvinnan. Genom inköp kunde hon förverkliga sina drömmar och skapa sig själv så som hon önskade. Varuhusen utgjorde även en arbetsplats för många kvinnor och kunde på så vis fungera som en väg till ekonomiskt självbestämmande. ${ }^{346}$ Som Lydia Wistisen har uppmärksammat är det en tematik som behandlas i svenska flickböcker från mitten av I900-talet. ${ }^{347}$ Oftare har dock varuhusmiljön och den moderna konsumtionskulturen sammankopplats med en objektifiering av kvinnan, vilket är den mer framträdande aspekten i Örnulfs roman. För Anna innebär de moderiktiga kläderna att hon på ett nytt sätt blir medveten om sin kropp och tjuskraft, vilket väninnan Hedvig hjälper henne att se i provrummet:

- Men tycker ni inte, att den är lite för urringad, sade Anna fundersamt. Jag vet inte hur det kommer sig, men jag tycker ...

- Din lilla toka, avbröt henne Hedvig leende, har man en sådan hals och sådana axlar som du, bör man inte vara rädd för att visa dem ... För det är verkligen vackert, medge det!

Anna svarade inte, men det syntes på hennes min, att hon delade sin väninnas mening. I själva verket var hon överförtjust. Nästan för första gången i sitt liv kände hon sig glad över att hon såg så bra ut och fann nöje i att bära vackra kläder. ${ }^{348}$ 
Klädshoppingen framställs som lustfylld, men gör ändå Anna till en främling inför sig själv allteftersom hon anammar andras ståndpunkter om vad hon bör ha på sig. Samtidigt som hon njuter av Stockholms nöjesliv känner hon sig förvirrad och olycklig över den förändring hon upplever i sig själv. Romanen skildrar ett kvinnoblivande via konsumtion, där flickan blir kvinna genom att tillägna sig rätt kläder och attribut. Förvandlingen gestaltas inte som ett uttryck för hennes personlighet utan som en kommodifiering, eller för att låna Peter Stoneleys ord: "Her education in consumerism [...] produces her as a commodity to be consumed." 349

Den vuxenhet som Anna introduceras i utmärks inte av ökad handlingskraft, förnöjsamhet eller ett socialt ansvarstagande, som i exempelvis Stadsflickor på landet. Medan de unga kvinnorna i Andersons roman blir attraktiva på äktenskapsmarknaden genom sina färdigheter i hushållning, får huvudpersonen i Anna Jernbielm i större utsträckning sitt värde genom en förmåga att utstråla kvinnlig skönhet och lyx. Som bland andra Krista Lysack påpekat kunde dottern och makan fungera som tecken för faderns respektive makens ekonomiska ställning under I 800-talet och det tidiga I900-talet. Genom sin klädsel iscensatte kvinnan hemmets välstånd och signalerade faderns/makens kreditvärdighet. ${ }^{350}$ Mannens goda ekonomi visades även genom att kvinnan inte behövde arbeta för familjens försörjning. I Anna Jernbielm öser fäderna pengar över sina döttrar och inget arbete eller ansvarstagande krävs i gengäld. Till skillnad från de rationella unga kvinnorna i flickböckernas hushållsskolor blir Anna försörjd av andra och har ingen insikt i ekonomiska realiteter.

Samma lättsinne kännetecknar en annan vanligt förekommande flickbokstyp: den fåfänga koketten som vill ha det senaste i modeväg och inte sällan lever över sina tillgångar. Dessa hedonistiska flickor lägger sina pengar på onyttiga och onödiga saker, såsom dyra kläder, nipper och dålig litteratur, och undviker praktiskt arbete. Karin i KuylenstiernaWensters Ungdomen på Hällesund beskrivs som "ett dockbarn med parisertoaletter, alltid vant att bäras på händerna och aktas för varje stöt".351 Hon vill bli uppassad och är ovan att ta hand om sig själv. Ett annat exempel utgörs av Julia i Meyersons Flickor emellan som efter en vistelse i 
Paris förvandlas till"en tanklös modedocka". ${ }^{352}$ Dessa kvinnor blir vuxna till ålder och genom äktenskap, men de förblir lika ansvarslösa och nöjeslystna. Om Julia berättas att hon efter sitt giftermål för "ett öfverflödigt och storståtligt lif i hufvudstaden och att löjtnanten [Julias make] gjort stora skulder, hvilka svärfadern fått betala". ${ }^{353}$ Julia uppnår aldrig den självkontroll eller självständighet som i Meyersons flickbok karakteriserar en vuxen, eftersträvad kvinnlighet. Hennes och makens ekonomiska oansvarighet gör dem fortsatt barnlikt beroende av sina föräldrar.

Anna går från att vara sin fars dotter till att lyda den framtida maken, som ser som sin uppgift att"med mild men fast hand leda den ystra sprakfålen Murre [Annas smeknamn] in på de rätta vägarna". ${ }^{354}$ Hon skiljer sig från den koketta flicktypen genom att hon genomgår en utveckling i samband med äktenskapet. På fästmannen Rudolfs inrådan skickas även denna unga kvinna till hushållsskola i den sista boken i trilogin, Anna Jernbielms lycka (I922), men såväl skolundervisningen som hennes skötsel av hushållet som gift förbigås i huvudsak med tystnad i boken. Ekonomi, arbete eller ansvarstagande har till skillnad från i flickböckerna om hushållsskolor ingen funktion $i$ hennes mognadsprocess. Den fokuserar i stället på att hon måste överge sina egna drömmar om lycka och anpassa sig efter männens behov. Anna Jernbielms lycka skildrar bröllopsresan och den desillusioneringsprocess den innebär för Anna, allteftersom hon upptäcker att maken saknar skönhetssinne och medkänsla med andra i affärer samt att han ringaktar kvinnor och inte heller har några högre tankar om hennes intellekt. Misstanken om att han är otrogen är dock det som slutligen åstadkommer"en fullständigt genomgripande förändring", så att"en helt ny personlighet strålade ut från hennes förtjusande lilla gestalt"., 355 Förvandlingen sker när den första ilskan har lagt sig och Anna inser dels vilken sorg det fallerade äktenskapet skulle innebära för hennes far, dels att hennes make riskerar att kasta sig i fördärvet och att hon måste rädda honom. Inte förrän hon ger upp sina egna önskningar och inriktar sig på faderns och makens bästa sägs hon bli vuxen: "[Det] var först i detta ögonblick, som friherrinnan Anna Sporre, född Jernhielm, förvandlades från barn till kvinna." ${ }^{356}$ Även om det visar sig att maken aldrig varit otrogen är förändringen oåterkallelig. Den utveckling som inleddes när 
hon anpassade sig efter andras klädsmak i provrummet fullbordas då hon prioriterar andras välmående framför sin egen lycka. Först då blir Anna verkligen kvinna.

\section{Nation och konsumtion}

Spänningen mellan rationell och hedonistisk konsumtion formuleras i flera av de ovan nämnda flickböckerna även som en motsättning mellan stad och land. En dylik motsättning är vanligt förekommande inom flickboksgenren i stort. ${ }^{357}$ Storstadslivet sägs i Strussenfelts Flickskolan på landet ha gjort Eugenie till"ett af dessa stolta sjelfiska väsenden, hvilka lefva och röra sig inom sin egen verld, och icke hafva en tanke eller känsla för andra", medan en Stockholmsvistelse har gjort Astrid "bra ytlig och fåfäng" i Kuylenstierna-Wensters När katten är borta -. En feriebistoria om fyra flickor och några till (I9I5). ${ }^{358}$ De likaledes själviska och koketta Karin i Kuylenstierna-Wensters Ungdomen på Hällesund och Julia i Meyersons Flickor emellan uttrycker en dragning till storstäder och utlandet. I Flickor emellan utgör Stockholm samtidigt en scen för utveckling och vidgade möjligheter, då flickorna där kan få en utbildning som småstaden inte kan tillhandahålla. Storstaden står i dessa berättelser för konsumtion, framsteg och modernitet, men också för ytlighet och en avsaknad av förankring i äldre, svenska traditioner och familjelivets stabila lugn. Andersons Stadsflickor på landet riktar fokus mot tematiken redan i titeln och förordet förtydligar:"Det är en känd och äfven mycket naturlig sak, att stadsbarn i allmänhet och stockholmsbarn i synnerhet hafva mycket oklara begrepp om hur det går till på landet." Författaren förklarar vidare att hon med sin bok önskar"väcka de uppväxande flickornas aktning och intresse för ett stilla hemlif och för de husliga sysslor, hvilka därmed höra tillsammans". ${ }^{359}$ Flickornas okunskap om de enklaste sysslor demonstreras genomgånde, vilket samtidigt understryker hur bristfälligt rustade för att sköta ett hem de blivit genom sin uppfostran i staden - både praktiskt och ekonomiskt.

Skillnaderna mellan stads- och lantliv aktualiserar frågor om olika materiella, sociala och emotionella värden. Kathleen Anne McHugh har i American Domesticity. From How-to Manuals to Hollywood Melodra- 
ma (I999) diskuterat den funktion hemarbetet hade i en övergång mellan självhushållning och marknadsekonomi i Nordamerika under I 800-talet. Målet för den strävsamma husmodern var inte att göra en vinst i sig utan att genom sparsamhet och flit göra hemmet ekonomiskt självständigt och oberoende av marknaden. Hushållsarbetet skapade samtidigt en känsla av samhörighet och gemenskap, vilket medförde att dess primära värde framställdes som symboliskt snarare än monetärt. ${ }^{360}$ På ett likartat sätt förespråkar flera av de diskuterade flickböckerna sparsamhet, men det ekonomiska tänkandet är underordnat kollektivets bästa och mer symboliska värden. Även om familjen Alin i Stadsflickor på landet har begränsade ekonomiska medel, beskrivs de som rika genom sin samhållning, fromhet och förmåga att urskilja tillvarons väsentligheter. Lantlivet i Andersons roman är fyllt av strävsamt och utvecklande arbete, men också av enkla, "billiga" nöjen som utflykter i närområdet, umgänge med grannarna och högläsning. Julen firas till exempel med familjen i gemenskap och stillhet, utan julklappshets, stora släktkalas eller sena kvällar som skymmer "hvarför man firar julen", ${ }^{361}$ Det är en fridfull tillvaro som följer årstidernas takt i naturens hägn och kan liknas vid ett äldre samhälles cykliska rytm, där varje arbetsuppgift, inköp och sedvänja hade sin bestämda tid. Denna cykel upplevdes runt sekelskiftet som hotad av industrialisering och de nya konsumtionsmönster som höll på att växa fram. ${ }^{362}$

I flera flickböcker om hushållsskolor signaleras även en distans till moderniteten och konsumtionssamhället genom en hög värdering av hantverk och hemgjorda ting, oavsett om det handlar om egenlagad mat eller konstfulla vävnader. Dessa texter exponerar att mat och andra varor flickorna köpt i staden är produkter från naturen och av mänskligt arbete. På frågan om hon kan spinna svarar en av eleverna i Stadsflickor på landet: "'Det behöfver man inte lära sig', upplyste Hulda, 'det är endast på fabrikerna de spinna."”363 Flickans alienation från klädernas ursprung är signifikativ. Enligt Runefelt hade de egentillverkade kläderna ett stort symbolvärde i I700-talets debatt som kännetecken för den goda husmodern. ${ }^{364}$ Att frågan fortsatt var aktuell runt sekelskiftet I900 tydliggörs av att hushållsskolorna i Andersons och Wides romaner ägnar mycket utrymme åt att lära flickorna vävnad och andra hantverk. 
Det faktum att lin växer på åkrar förvånar en annan av flickorna i Stadsflickor på landet, vilket leder till att mor Brita redogör för traditionell lintillverkning, från frösådd till vävning. Scenen visar hur gamla seder har glömts bort i det moderna livet och att det betraktas som en förlust understryks av allmogekvinnans förargelse över "att nutidens ungdom kunde vara så okunnig". ${ }^{365}$ Även eleverna i Kamraterna på Forsbro ivrar för äldre sedvänjor, i synnerhet "väfvnadens vackra och fosterländska id". ${ }^{366}$ I båda dessa berättelser ges hantverk och olika former av lantarbete ett symboliskt värde, frikopplat från ekonomi eller produktivitet. Kunskap om traditionell lintillverkning är möjligen överfödig i ett industrialiserat stadsliv, men den beskrivs som värdefull på grund av sin förmåga att överbrygga den alienation som det moderna livet fört med sig. Lantlivet och hushållssysslorna gestaltas på så vis som mer genuina än stadstillvaron och tillskrivs särskilda värden genom sin association med fosterländskhet, ursprunglighet och tradition.

Liksom flickorna i Wollstonecrafts och Strussenfelts romaner får eleverna på Granliden lära sig värdet i att hjälpa andra och att skatta glädjen i att ge till bättre behövande högre än tillfredsställelsen över att få eller köpa saker till sig själv. I stället för julgåvor från paret Alin bereds flickorna "ett litet nöje" genom att de får dela ut mat till bygdens fattiga och flickorna föreslår själva ivrigt att de också ska skänka bort sina julklappspengar. ${ }^{367}$ Hushållningen leder således inte till att resurserna läggs på hög utan i den mån det finns ett överskott används det till att hjälpa andra snarare än till att förbättra den egna ekonomiska situationen. Därigenom förstärks samhörigheten såväl inom hemmet som i lokalsamhället. Det finns en spänning i dessa flickböcker mellan beskrivningen av hushållsarbetet som å ena sidan altruistiskt och å andra sidan en försörjningsmöjlighet för individen i ett modernt samhälle. När de unga kvinnorna tvingas ut $\mathrm{i}$ arbete sker det dock, som påpekats tidigare, ofta som en följd av familjefädernas konkurs eller skuldsättning och att de lämnas helt utan eller med otillräckligt stöd. Därigenom markeras att annorlunda förhållanden råder i det moderna samhället, genom att marknadsekonomin satt tidigare sociala och ekonomiska lojalitetsband ur spel. ${ }^{368}$ Även om exempelvis Bråkenhielms Marja och hennes syskon skildrar hur huvudpersonens drömmar förverkligas med hjälp av en rik 
välgörare, beskriver sekelskiftets svenska flickböcker oftare hur unga kvinnor inte kan räkna med att bli omhändertagna. De måste kunna försörja sig själva. Andersons Stadsflickor på landet formulerar en nostalgi över och en strävan efter att hålla kvar vid vad som framställs som en äldre tids sociala ansvarskänsla, men texten synliggör också samtidens mer krassa ekonomiska realiteter.

Idealiseringen av lantlivet återfinns även i Örnulfs flickbokstrilogi i form av Annas och faderns kärlek till sitt lantgods. I dessa romaner tillskrivs dock nostalgin över ett nationellt förflutet ett mer begränsat värde. Böckerna om Anna Jernhielm tillhör några av de få i undersökningsmaterialet som ohämmat bejakar marknadsekonomi, frihandel och hedonistisk konsumtion. Annas fästman Rudolf, som får vara modernitetens och rationalitetens förespråkare i berättelserna, är en internationell affärsman involverad i koloniala företag. Han betraktar även den vackra svenska naturen som en outnyttjad resurs av råvaror, vilket tydliggörs i Anna Jernhielms friare. Major Jernhielms sentimentala och gammalmodiga sätt att driva sitt lantbruk framställs som grunden för hans ekonomiska problem. Skogen betraktas av majoren som "arvet till våra efterkommande" och har därför inte rörts, medan Rudolf föreslår att delar av den ska avverkas och säljas"nu när pappersveden står så högt i pris" ${ }^{369}$ Godsets vackra sjö kan därtill dämmas upp och den erhållna vattenkraften ligga till grund för en såg och ett pappersbruk. Majorens värdering av tradition och naturens skönhetsvärden får i romanen ge vika för Rudolfs affärsblick och strävan efter att omvandla naturresurser till reda pengar. På ett liknande sätt ställs i Anna Jernbielms lycka Annas känslobetonade förhållningssätt till affärer mot Rudolfs rationella vinstintresse. Hon försöker övertyga maken om att ge en annan affärsman uppskov med avbetalningen på en skuld för att familjen inte ska drabbas av hans konkurs, men Rudolf är obeveklig:"Hela hans affär har gått och går baklänges, den sköts inte på det rätta sättet och vi få inte se skymten av våra pengar om vi låta honom fortsätta." ${ }^{370}$ Inte heller känner Rudolf något medlidande gentemot den svarte, afrikanske arbetare som piskas offentligt på affärskompanjonens order. Han menar att det är"rätta sättet att kuva och göra folk av råa vildar ${ }^{371}$ Det är ett kolonialt betraktelsesätt där såväl människor som naturresurser utgör råvaror för förädling 
och vinst, och denna ståndpunkt har $\mathrm{i}$ romanen berättarens sympati.

Om den rationella konsumenten prioriterar sparande och att maximera utnyttjandet av befintliga resurser, framstår det inom marknadsekonomins logik som mer rationellt att sträva efter en maximering av vinst genom investeringar, handel och ohämmad konsumtion. Affärslivets rationalitet handlar i böckerna om Anna Jernhielm om att inte styras av sentimentalitet eller känslor i relation till pengar. Inte heller nationella hänsyn tycks ges någon vikt utan vinsten är det huvudsakliga. Det ekonomiska systemet sammankopplas vidare med en könsstruktur, där mannen skapar pengar genom affärer och investeringar, medan kvinnan är den hedonistiska konsumenten som genom sina inköp gynnar marknaden. ${ }^{372}$ Det är den enda funktion hon har i det offentliga livet. Annas sfär blir familjelivets och hon saknar samhälleligt inflytande, men tycks inte heller eftersträva något sådant. Den välgörenhet och vördnad för traditioner som i Stadsflickor på landet utgjorde väsentliga värden för samhället och som möjliggjorde en vidgad verksamhetskrets för kvinnan, avvisas i Örnulfs trilogi som irrationella och ett hot mot en stabil ekonomi.

Hushållnings- och konsumtionsmönstren ingår i de analyserade flickböckerna i en moralisk och fostrande medborgardiskurs, som fungerar kvalificerande eller diskvalificerande för större självbestämmande och ett utökat samhällsinflytande. Som Felski poängterat fanns betydande samband mellan utvecklingen av en modern konsumtionskultur och kvinnors strävan efter utökade medborgerliga rättigheter. Hon konstaterar att"the interpellation of middle-class women as consumers in the late nineteenth century undoubtedly bore a significant relationship to their rising expectations and their increasingly vocal political demands" ${ }^{373}$ Den brittiska rösträttsrörelsen använde sig även av konsumentmakt för att främja sin sak, bland annat genom att handla i affärer som offentligt gav sitt stöd till kvinnors rösträtt och krossa skyltfönstren på dem som inte gjorde det. ${ }^{374}$ Inom kvinnorörelsen fanns emellertid en skepsis gentemot framställningar av kvinnlig hedonism och man föredrog $\mathrm{i}$ stället bilden av kvinnan som rationell konsument. ${ }^{375}$ I mitt undersök- 
ningsmaterial uttrycks en likartad tvekan inför den hedonistiska flickan. Majoriteten av texterna formulerar ett sparsamhetsideal baserat på rationell konsumtion och hushållning, vilket kontrasteras mot vad som framställs som det moderna konsumtionssamhällets slöseri, hedonism och växlande moden.

Hushållning $i$ hemmen får i förlängningen en parallell i en hushållning av landets resurser. Den oansvariga och arbetsovilliga kvinnan måste i de analyserade texterna antingen genomgå en reformering eller stanna i privatsfären och förbli ekonomiskt beroende av andra. De kvinnor som lärt sig att vara flitiga och sparsamma ges däremot tillträde till ett vidare verksamhetsfält. Medan Anna i Örnulfs flickbokstrilogi förbereds för att bli gift och lär sig att underordna sig sin make, tränas flickorna i hushållsskolorna i Stadsflickor på landet och Kamraterna på Forsbro för att bli aktiva samhällsmedborgare som förmår agera i nationens intresse, exempelvis genom att utöva välgörenhet eller att själva undervisa nya generationer kvinnor i hushållningens konst. I det förra exemplet produceras den unga kvinnan som objekt i en patriarkal ekonomi, i de senare som självbestämmande subjekt. Associationen mellan lyxkonsumtion, stadsliv och utländskhet i flera av texterna synliggör därtill nationalistiska underströmmar i idealiseringen av husmoderns sparsamhet. De analyserade romanerna visar hur flickan kan bidra till familjens och nationens välstånd genom såväl inköpsvanor och hushållning i det privata som samhällsreformatoriska insatser i offentligheten. På så vis kan dessa flickböcker sägas förespråka en mobilisering av de unga kvinnorna i nationens tjänst, antingen i eller utanför hemmet. 